\title{
PENGGUNAAN METODE FERNALD UNTUK MENINGKATKAN PRESTASI MEMBACA BRAILLE BAGI SISWA TUNANETRA KELAS II DI SLB-A TPA JEMBER SEMESTER II TAHUN AJARAN 2017/2018
}

\author{
Sudartiningtyas, S.Pd \\ SLB-A TPA Jember \\ Email: sudartiningtyas@gmail.com
}

\begin{abstract}
Abstrak
Keterampilan membaca perlu dimiliki oleh setiap orang, baik orang normal maupun orang yang memiliki hambatan. Bagi tunanetra yang total, kegiatan membaca dengan menggunakan ujung-ujung jarinya, sedangkan bagi tunanetra low vision dianjurkan memaksimalkan sisa penglihatan yang masih dimiliki. Subyek penelitian adalah Siswa Tunanetra Kelas II di SLB-A TPA Jember semester genap Tahun Ajaran 2017/2018. Teknik pengumpulan data yang digunakan adalah adalah tes, observasi dan interview. Analisis data menggunakan analisis komperatif dengan grafik, yaitu membandingkan kondisi nilai tes awal siklus I dan tes setelah siklus II, masing -masing siklus terdiri dari perencanaan (planing), tindakan (acting), pengamatan, dan refleksi. Metode yang digunakan adalah metode Fernald atau metode VAKT (Visual, Auditory, Kinestetic and Taktik). Setelah penggunaan Metode Fernald, diperoleh nilai terendah tiap fasenya selalu ada kenaikan. Pada pra-siklus nilai terendah 50, pada siklus I menjadi 55, sedangkan pada siklus II meningkat menjadi 70. Perolehan nilai tertinggi pada pra-siklus 60, pada siklus I meningkat menjadi 70, dan pada siklus II meningkat lagi menjadi 85. Kenaikan juga terlihat pada nilai rata-rata. Pada pra-siklus nilai rata-rata 55, siklus I naik menjadi 63,33 dan pada siklus II meningkat menjadi 70,33. Pencapaian ketuntasan belajar juga mengalami peningkatan. Pada pra-siklus 0\%, siklus I meningkat menjadi 66,67\% dan pada siklus II meningkat menjadi 100\%. Berdasarkan penelitian tersebut, diambil kesimpulan bahwa Penggunaan Metode Fernald dapat Meningkatkan Prestasi Membaca Braille Bagi Siswa Tunanetra Kelas II di SLB-A TPA Jember semester genap Tahun
\end{abstract} Ajaran 2017/2018.

Kata Kunci: Metode Fernald, Tunanetra, Tulisan Braille.

\section{PENDAHULUAN}

Keterampilan membaca perlu dimiliki oleh setiap orang, baik orang normal maupun orang yang memiliki hambatan tak terkecuali anak tunanetra, agar mereka seperti anak normal pada umumnya. Tempat belajar yang sesuai adalah di SLB-A atau di SDLB agar mereka mendapat pelajaran secara khusus dengan hambatan belajar yang dimilikinya, yang karena ketidaknormalan penglihatan mempengaruhi cara membaca mereka.

Usaha untuk memiliki kemampuan prestasi membaca sudah tentu harus dimulai sedini mungkin, dimulai dari lingkungan keluarga dan juga lingkungan sekolah. Peran guru dan orangtua sangat besar bagi anak tunanetra untuk giat membaca.

Bagi tunanetra yang total kegiatan membaca dengan menggunakan ujung-ujung jarinya, bukan menggunakan penglihatannya, sedangkan bagi tunanetra low vision dianjurkan memaksimalkan sisa penglihatan yang masih dimilikinya. Sehingga untuk bisa membaca dapat melalui latihan membaca huruf yang diperbesar atau melalui tulisan Braille dan jika ingin membaca harus melatih 
ujung-ujung jarinya untuk membaca tulisan Braille yang terdiri dari 6 titik.

Metode yang sudah lazim yaitu SAS dan Drill ternyata masih juga belum berhasil dengan memuaskan. Ternyata nilai rata-rata harian membaca adalah seperti data di bawah ini:

Tabel 1. Hasil Belajar Membaca

\begin{tabular}{|c|l|c|}
\hline NO & \multicolumn{1}{|c|}{ NAMA SISWA } & NILAI \\
1 & Bani Roihan & 55 \\
\hline 2 & Aprilia & 60 \\
\hline 3 & R, Mikail W. & 50 \\
\hline
\end{tabular}

Sumber : Sudartiningtyas (2020)

Rendahnya perstasi membaca kelas dipengaruhi oleh beberapa faktor, antara lain:

1. Faktor intern anak tunanetra itu sendiri, yaitu tingkat ketajaman penglihatan dan motivasi intern.

2. Faktor ekstern, yaitu berupa media pembelajaran, buku bacaan, kesiapan, dan pengalaman guru, metode pembelajaran.

Bertitik tolak dari masalah tersebut, guru berusaha untuk menangani permasalahan tersebut dengan cara mengajarkan membaca pada anak tunanetra dengan menggunakan Metode Fernald. Metode Fernald ini menggunakan materi bacaan dari kata-kata yang diucapkan anak dan tiap kata diajarkan secara utuh. Metode ini ada empat tahapan yaitu:

1. Guru menulis kata, kemudian anak menyelusuri dengan jarinya. Tahap berikutnya, anak mengucapkan kata tersebut, kemudian menulis dan membacanya.

2. Anak bebas mempelajari kata sendiri dengan mengucapkan kemudian menulis

3. Anak membuat kata, mengucapkannya sebelum menulis

4. Anak mampu mengingat kata-kata baru berdasarkan kemiripan katakata yang telah dipelajarinya.

Hal ini dilakukan berulangulang sampai anak benar-benar bisa menulis dan membaca tanpa dibantu guru.

Penelitian ini bertujuan untuk mendeskripsikan Penggunaan Metode Fernald dalam meningkatkan prestasi membaca Braille bagi siswa tunanetra Kelas II di SLB-A TPA Jember Tahun Ajaran 2017/2018.

\section{METODE}

Penelitian ini melalui proses yang akan dilaksanakan dua siklus. Setiap siklus selama dua minggu. Adapun pelaksanaan disesuaikan dengan jadwal yang ada.

Rincian. Penelitian tindakan kelas dilakukan di kelas II tahun pelajaran 2017/2018, yang merupakan tempat peneliti melaksanakan tugas mengajar sebagai guru bidang studi Bahasa. Penelitian ini dilakukan di kelas II karena siswa memiliki permasalahan sesuai dengan yang akan diteliti. Adapun jumlah siswa yang akan diteliti 3 orang. Sumber data diperoleh dari semua siswa kelas II yang dianggap dapat memberikan informasi mengenai hal-hal yang 
dianggap perlu. Selain mengobservasi siswa, peneliti juga minta pendapat dari wali kelas II dan teman-teman sejawat yang mengajar di SLB-A TPA Jember. Dalam penelitian ini teknik pengumpulan data yang digunakan adalah tes, observasi dan interview.

Informasi yang akan dijadikan data penelitian perlu diperiksa kevaliditasannya sehingga data tersebut dapat dijadikan sebagai dasar yang kuat dalam menarik kesimpulan. Teknik yang digunakan untuk memeriksa validitas data antara lain adalah triangulasi dan review informasi kunci. Triangulasi adalah teknik pemeriksaan validasi data dengan memanfaatkan sarana diluar data untuk keperluan pengecekan atau pembanding data inti. Review informasi kunci adalah mengkonfirmasikan data atau interprestasi temuan kepada informan kunci sehingga diperoleh kesepakatan antara penelitidan informasi tentang data atau interprestasi temuan tersebut.

Indikator kerja atau rumusan kinerja yang dijadikan acuan dalam menentukan keberhasilan peningkatan prestasi membaca Braille dengan metode Fernald bagi siswa tunanetra kelas II adalah anak yang memperoleh nilai 6,5 lebih dari 75\% nilai rata -rata membaca meningkat dari 5,5 menjadi 6,5 .

Penelitian dilakukan dengan menggunakan metode penelitian tindakan kelas yang dilakukan dalam 2 (dua) siklus dan dari masing -masing siklus terdiri dari perencanaan (planing), tindakan (acting), pengamatan, refleksi

\section{HASIL DAN PEMBAHASAN}

Perolehan nilai terendah tiap fasenya selalu ada kenaikan. Pada prasiklus nilai terendah 50, pada siklus I menjadi 55, sedangkan pada siklus II meningkat menjadi 70. Perolehan nilai tertinggi pada pra-siklus 60, pada siklus I meningkat menjadi 70, dan pada siklus II meningkat lagi menjadi 85. Kenaikan juga terlihat pada nilai ratarata. Pada pra-siklus nilai rata-rata 55, siklus I naik menjadi 63,33 dan pada siklus II meningkat menjadi 70,33. Pencapaian ketuntasan belajar juga mengalami peningkatan. Pada prasiklus $0 \%$, siklus I meningkat menjadi $66,67 \%$ dan pada siklus II meningkat menjadi $100 \%$.

Dari penelitian yang telah dilakukan, hasil prestasi pembelajaran dari ketiga siswa mengalami peningkatan yang cukup memuaskan, karena target dari penelitian ini hanya diharapkan rata-rata kelas 65 tetapi hasilnya rata-rata kelas siklus I 63,33 dan siklus II 70,33. Begitu pula dari hasil observasi minat belajar menunjukkan peningkatan dalam konsentrasi, keaktifan, dan keantusiasan siswa dalam mengikuti pembelajaran.

Dengan demikian dapat disimpulkan bahwa dengan menggunakan Metode Fernald dapat meningkatkan prestasi membaca Braille bagi siswa tunanetra Kelas II di SLB-A TPA Jember Tahun Ajaran 
2017/2018 meningkat teruji

kebenarannya.

Kelebihan dari Metode Fernald adalah

1. Siswa lebih bergairah dalam mengikuti pelajaran membaca Braille

2. Tahapan-tahapan dalam kegiatan membaca juga dapat dijalankan dengan baik.

3. Daya saing antar siswa semakin meningkat terutama pada penggunaan Metode Fernald tahap I dan II

Sedangkan kelemahan dari Metode Fernald ini adalah siswa menjadi bosan manakala menginjak pada tahap III dan IV dalam Metode Fernald yaitu jika siswa disuruh membaca buku bacaan tanpa menggunakan papan baca terlebih dahulu.

Untuk mempertahankan dan mengatasi kelemahan maka diperlukan upaya yang lebih maksimal agar mendapatkan hasil yang lebih baik. Dari hasil observasi dan pelaksanaan pembelajaran siklus I dan siklus II menunjukkan perubahan yang sangat positif pada konsentrasi, keaktifan dan prestasi siswa. Perubahan prestasi sisa juga diperkuat dengan hasil tes selama siklus I dan siklus II.

\section{PENUTUP}

\section{Simpulan}

Dari hasil kegiatan pembelajaran yang telah dilakukan selama dua siklus, dan berdasarkan seluruh pembahasan serta analisis yang telah dilakukan dapat disimpulkan bahwa penggunaan Metode Fernald dapat meningkatkan prestasi membaca Braille bagi siswa tunanetra kelas II di SLB-A TPA Jember tahun ajaran 2017/2018.

\section{Saran}

Pembelajaran membaca Braille dengan Metode Fernald dalam pembelajaran Bahasa Indonesia pada aspek membaca Braille sangat diperlukan agar siswa dapat meningkatkan prestasinya. Sehubungan dengan hal tersebut disarankan :

1. Bagi siswa hendaknya dapat mengoptimalkan penggunaan metode Fernald dalam membaca Braille.

2. Bagi peneliti lanjut hendaknya penelitian ini dapat dikembangkan agar prestasi membaca Braille kelas II di SLB-A TPA Jember tahun ajaran 2017/2018 meningkat.

\section{DAFTAR PUSTAKA}

Anton Sukarno, 2002. Pengantar Statistik, Surakarta: UNS Press.

Beni Ahmad Saebani, 2007, Metode Penelitian, Bandung, Pustaka Setia.

Bimo Walgito, 1980 Bimbingan Penyuluhan, Yogyakarta : Yayasan Penerbit Psikologi UGM 
Bratanata SA, Ny. Pedoman Menulis Braille Menurut Ejaan yang Disempurnakan, Jakarta. Depdikbud.

DepDik Nas, 2000, Sistim Braille Indonesia Bidang Bahasa Indonesia, Jakarta: Dep Dik Nas.

Direktorat PLB, 2004 Informasi Pelayanan Pendidikan Bagi anak Tuna Netra Jakarta: Dep Dik Nas.

Frans Harsono, 1984, Ortodidaktit Anak Tunanetra, Jakarta: Percetakan Negara RI. http//www.immimandala. blogspot.com. http://www.groups.com

Mulyono Abdurahman, 1995, Pendidikan Bagi Anak Berkesulitan Belajar, Jakarta: IKIP Jakarta Press.

Munawir Yusuf dkk, 2003. Pendidikan bagi anak dengan problema belajar, Solo: Tiga Serangkai

Munzayanah, 2007. Perkembangan peserta didik, Hand Out Mata Kuliah Surakarta. Parwoto, 2007, Strategi Pembelajaran Anak Berkebutuhan Khusus, Jakarta, Depdiknas.

Purwoko Hadi, 2007, Komunikasi Aktif Bagi Tunenetra: Jakarta, Depdiknas.

Rini Hildayani, 2006, Penanganan Anak Berkelainan, Jakarta: Universitas Terbuka. Sapari Imam Asyari, 1983. Metodologi
Penelitian Sosial, Surabaya: Usaha Nasional. Sarwiji Suwandi, 2008, Penelitian Tindakan Kelas, Surakarta, UNS.

Suharsini Arikunto, 1989, Manajemen Penelitian, Jakarta: Dirjen Dikti, Depdikbud. Tien Supartinah MS, 1995, Psikologi Anak Luar Biasa, Surakarta : UNS Press. www. Geocities. Com. 